\title{
Geotechnical Engineering Properties of Fly Ash and Bottom Ash: Use as Civil Engineering Construction Material
}

\author{
P. G. S. Gimhan, J. P. B. Disanayaka and M. C. M. Nasvi
}

\begin{abstract}
Norochcholai coal power plant is the largest coal power plant in Sri Lanka and during the combustion of coalit annually generates about 250,000 metric tons of coal ash which consists of fly ash (FA) and bottom ash (BA). Almost all the generated ash is disposed into ash dumps except a small quantity of FA (30\%) that is effectively utilized. Therefore, use of coal ash for construction purposes will offer a sustainable solution for reducing its by-products and overcoming the scarcity of raw materials required for construction work. The main aim of this research was therefore to determine the geotechnical engineering properties of FA and BA to find out the feasibility of using them as light weight embankment or backfill material. A series of laboratory experiments were conducted on FA, BA and FA-BA co-mixed samples to determine their particle size distribution, specific gravity, index properties, compaction characteristics, shear strength parameters and California bearing ratio (CBR). The experimental results reveal that the particle size of coal ash (FA and BA) is predominantly silt sized while containing some sand-sized fractions as well. This coal ash has a low maximum dry density (MDD) and a high optimum moisture content (OMC) compared to typical granular soils used in embankments. In addition, this ash has a higher friction angle and higher cohesion than most types of construction fills. Thus, both FA and BA can be used as light weight embankment or back fill material in civil engineering construction work.
\end{abstract}

Keywords: $\quad$ Bottom Ash; Coal; Compaction; Embankment; Fly Ash; Friction Angle

\section{Introduction}

Lakvijaya coal power plant in Norochcholai is the largest coal power plant in Sri Lanka. At present, the power generated by this power plant meets about $50 \%$ of the daily electricity requirement of Sri Lanka. According to Ceylon Electricity Board (CEB), in the year 2021, coal power plants will be the major sources of power generation (i.e. 84\%). During its power generation, Lakvijaya coal power station continuously generates fly ash (FA) and bottom ash (BA) as by-products of its coal burning process. The plant produces about 50,000 metric tons of BA and 200,000 metric tons of FA per annum. Of the total amount of FA produced, a small portion is used for cement production by Siam City (Lanka) Ltd and the remaining FA ends up in a dump yard incurring additional costs.

The dump yard of the power plant is located about $100 \mathrm{~m}$ away from it. The plant has only this dump yard and already a large area of it has been covered with the dumped ash. Land where ash could be dumped is now scarce and the dust emitted by the already dumped ash spreads to nearby settlements. This has made the people living in the surrounding settlements to start complaining and protesting against the dust emissions.

Currently, there is a scarcity of natural resources, especially fine aggregates, required for construction purposes. This has caused a shortage of backfill material and lightweight embankment material required for construction work. Due to their increased use, these natural materials have become scarce, and there is an urgent requirement to be ready with alternatives to them. Coal ash produced in the Lakvijayaplant can be used to meet this requirement which will provide a sustainable solution because of its advantages: (1) its byproducts can be used in construction and this will eliminate the land pollution problems associated with dump yards and reduce the

Mr. P.G.S. Gimhan, B.Sc. Eng. (Hons.)(Peradeniya), Department of Civil Engineering, University of Peradeniya. Email:samurdagimahn@gmail.com

Mr. J.P.B. Disanayaka, B.Sc. Eng. (Hons.)(Peradeniya), Department of Civil Engineering, University of Peradeniya. Email:disanayakajpb@gmail.com

Eng. (Dr.) M.C.M. Nasvi, B.Sc. Eng. (Hons.)

(Peradeniya), PhD(Monash), AMIE (Sri Lanka), Senior Lecturer of Civil Engineering, Department of Civil

Engineering, University of Peradeniya.

Email:nasvimcm@eng.pdn.ac.lk 
cost and energy of land filling, and (2) it will solve the problem of scarcity of granular materials required in construction applications. Other countries such as India and USA in the world have already started utilizing their FA in construction work including highway construction.

There have been many studies $[1-4,6,7,9,11]$ on the suitability of coal ash for construction applications. A summary of these studies and their key findings are given in Table 1. It can be seen from Table 1 that coal ash such as FA and BA can be used as light weight embankment or backfill material. However to date, there have been no studies focusing on the geotechnical engineering properties of coal ash obtained from the Lakvijaya coal power plant in Sri Lanka. Therefore, the main aim of this research was to study the geotechnical engineering properties of coal ash (FA and BA) produced by the Lakvijaya power plant, to find out the feasibility of using it as light weight embankment or construction material. A series of experiments including grain size analysis, and specific gravity, Atterberg limit, Proctor compaction and CBR tests were conducted on FA and BA samples obtained from the Lakvijaya coal power plant.

\section{Materials and Methods}

\subsection{Materials}

FA and BA samples used in the study were collected from the Lakvijaya power plant, Norochcholai, Sri Lanka. The chemical composition of the ash can vary depending on the coal type and coal combustion method. The coal used in the Lakvijaya plant is imported from Indonesia and the method of coal combustion at the plant does not vary with time.

Table 1 - Summary of findings from the literature

\begin{tabular}{|c|c|c|c|}
\hline Reference & $\begin{array}{l}\text { Type of ash } \\
\text { used in the } \\
\text { study }\end{array}$ & Geotechnical properties & Outcome of the study \\
\hline $\begin{array}{l}\text { Singh et al. } \\
\text { [11] }\end{array}$ & FA & $\begin{array}{l}\text { Specific Gravity }\left(\mathrm{G}_{\mathrm{s}}\right)=2.2 \text {; Liquid } \\
\text { Limit }(\mathrm{LL})=45-47 \% \text {; Maximum } \\
\text { Dry Density }(\mathrm{MDD})=1224 \mathrm{~kg} / \mathrm{m}^{3} \text {; } \\
\text { Optimum Moisture Content } \\
(\mathrm{OMC})=36 \%\end{array}$ & $\begin{array}{l}\text { FA can be used as a } \\
\text { highway embankment } \\
\text { material as a cost effective } \\
\text { solution. }\end{array}$ \\
\hline $\begin{array}{l}\text { Kanirajand } \\
\text { Gayathri } \\
\text { [2] }\end{array}$ & FA & $\begin{array}{l}\mathrm{LL}=30.5 \% ; \mathrm{MDD}=1380 \mathrm{~kg} / \mathrm{m}^{3} ; \\
\mathrm{OMC}=21 \% ; \text { Cohesion }(c)=12.6 \\
\mathrm{kN} / \mathrm{m}^{2} ; \text { Angle of Internal Friction } \\
(\phi)=29.3-31^{0}\end{array}$ & $\begin{array}{l}\text { FA can be used as a } \\
\text { foundation material or an } \\
\text { embankment fill material. }\end{array}$ \\
\hline $\begin{array}{l}\text { Kumar and } \\
\text { Stewart [4] }\end{array}$ & BA & $\mathrm{MDD}=1480 \mathrm{~kg} / \mathrm{m}^{3} ; \quad \mathrm{OMC}=15 \%$ & $\begin{array}{l}\text { BA can be used in } \\
\text { geotechnical applications. }\end{array}$ \\
\hline Pandian [9] & FA and BA & $\begin{array}{l}\text { Uniformity Coefficient }\left(C_{u}\right)=1.59- \\
17 ; \text { Coefficient of Curvature }\left(C_{c}\right)= \\
0.61-3.70 ; G_{s}=1.46-2.66 ; L L=22- \\
51\end{array}$ & $\begin{array}{l}\text { FA and BA are suitable for } \\
\text { the construction of } \\
\text { embankments and for the } \\
\text { filling up of low-lying areas. }\end{array}$ \\
\hline $\begin{array}{l}\text { Havanagi } \\
\text { et al. [1] }\end{array}$ & $\begin{array}{l}\text { FA and BA } \\
\text { (Pond Ash) }\end{array}$ & $\begin{array}{l}\mathrm{G}_{\mathrm{s}}=2.29 ; \mathrm{MDD}=1350 \\
\mathrm{~kg} / \mathrm{m}^{3} ; \mathrm{OMC}=18 \% ; \mathrm{C}=0 \mathrm{kN} / \mathrm{m}^{2} ; \\
\phi=31^{0}\end{array}$ & $\begin{array}{l}\text { Composite ash has potential } \\
\text { for use as a fill material in } \\
\text { railway embankments. }\end{array}$ \\
\hline $\begin{array}{l}\text { Muhunthan } \\
\text { et al. [7] }\end{array}$ & $\begin{array}{l}\text { FA: BA =0:100, } \\
20: 80,40: 60 \\
60: 40,80: 20 \\
100: 0\end{array}$ & $\begin{array}{l}\mathrm{MDD}=1220-1500 \mathrm{~kg} / \mathrm{m}^{3} \\
\mathrm{OMC}=26-43 \%\end{array}$ & $\begin{array}{l}\text { Ash is a very good fill or } \\
\text { embankment material. }\end{array}$ \\
\hline $\begin{array}{l}\text { Kim et al. } \\
{[3]}\end{array}$ & $\begin{array}{l}\text { FA: } \mathrm{BA}=100: 0 \\
75: 25,50: 50 \\
0: 100\end{array}$ & $\begin{array}{l}\mathrm{MDD}=1420-1750 \mathrm{~kg} / \mathrm{m}^{3} ; \mathrm{OMC}= \\
15.5-24.0 \% ; \mathrm{C}_{\mathrm{u}}=10.3-40.0 ; \mathrm{C}_{\mathrm{c}} \\
=0.40-2.98\end{array}$ & $\begin{array}{l}\text { Composite ash can be used } \\
\text { as a conventional fill } \\
\text { material. }\end{array}$ \\
\hline
\end{tabular}


The typical chemical composition of FA and BA produced in the plant is shown in Table 2.

Table 2 - Typical chemical composition of coalash [10]

\begin{tabular}{|l|c|c|}
\hline \multirow{2}{*}{ Compound } & \multicolumn{2}{|c|}{ Percentage, \% } \\
\cline { 2 - 3 } & $\begin{array}{c}\text { Fly } \\
\text { ash }\end{array}$ & $\begin{array}{c}\text { Bottom } \\
\text { ash }\end{array}$ \\
\hline Silicon Dioxide $\left(\mathrm{SiO}_{2}\right)$ & 52.0 & 46.1 \\
\hline Aluminum $\mathrm{Oxide}\left(\mathrm{Al}_{2} \mathrm{O}_{3}\right)$ & 32.3 & 23.7 \\
\hline Iron Oxide $\left(\mathrm{Fe}_{2} \mathrm{O}_{3}\right)$ & 7.0 & 5.8 \\
\hline Calcium Oxide $(\mathrm{CaO})$ & 5.6 & 7.0 \\
\hline Magnesium $\mathrm{Oxide}(\mathrm{MgO})$ & 1.3 & 1.2 \\
\hline Sodium Oxide $\left(\mathrm{Na}_{2} \mathrm{O}\right)$ & 1.0 & 0.7 \\
\hline Potassium Oxide $\left(\mathrm{K}_{2} \mathrm{O}\right)$ & 0.7 & 1.2 \\
\hline Sulfur Trioxide $\left(\mathrm{SO}_{3}\right)$ & 0.1 & - \\
\hline Loss On Ignition $(\mathrm{L} . \mathrm{O} . \mathrm{I})$. & - & 14.3 \\
\hline
\end{tabular}

Three FA samples (FA1, FA2 and FA3) and three BA samples (BA1, BA2 and BA3) were taken from six different locations in the dump yard to ensure reliability of the test results. Ash which had been dumped during the previous week and not segregated and disturbed was taken using a shovel. The three FA samples were labelled as FA1, FA2 and FA3 while the three BA samples were labelled as BA1, BA2 and $\mathrm{BA} 3$ according to the locations from which they were obtained. The ash samples were riffled to get an appropriate sample quantity for each test. Altogether nine different samples were tested from FA, BA and FA-BA co-mixed samples. Three different types of composite samples were prepared with a FA to BA ratio of 1:4, 1:1 and 4:1 and labelled as: (1) C1 - 20\% FA and $80 \%$ BA, (2) $\mathrm{C} 2-50 \% \mathrm{FA}$ and $50 \% \mathrm{BA}$, and (3) $\mathrm{C} 3-80 \% \mathrm{FA}$ and $20 \% \mathrm{BA}$.

\subsection{Experimental Methodology}

Index property tests including grain size analysis (BS 1377: Part 2: 1990), specific gravity test (BS 1377: Part 2: 1990) and Atterberg limit (BS 1377: Part 2: 1990) test were conducted on all the samples to determine their particle gradations, specific gravities and consistency limits (PL, LL and PI) respectively.

The Standard Proctor Compaction Test (BS 1377: Part 4: 1990) was carried out to obtain the optimum moisture content (OMC) and maximum dry density (MDD) of each coal ash sample. For this test, a mold $152 \mathrm{~mm}$ in diameter with a height of $127 \mathrm{~mm}$ was used for each sample which was compacted in 3 layers by applying 27 blows per layer using a $2.5 \mathrm{~kg}$ metal hammer. Two samples, one from the top and the other from the bottom, were taken to measure the moisture content. The average of the two measurements was taken as the moisture content of the sample. Moisture content against dry density was plotted to obtain the compaction curve. From the compaction curve, OMC and MDD were obtained.

Direct shear test (BS 1377: Part 7: 1990) was conducted to obtain the shear strength parameters (c and $\phi$ ) of the coal ash. For this test, a direct shear box $60 \mathrm{~mm} \times 60 \mathrm{~mm}$ in size was used with a shearing rate of $0.05 \mathrm{~mm} / \mathrm{min}$. Samples for the direct shear test were prepared in the CBR mold at OMC obtained from the standard compaction test. The CBR mold was filled with 3 layers and 62 blows were applied to each layer. The samples were then extruded from the CBR mold using the direct shear box. The test was conducted at the normal stresses (ఠ) $50,100,150 \mathrm{kPa}$ and was terminated when shear failure occurred.

California bearing ratio (CBR) test (BS 1377: Part 4: 1990) was conducted to check the bearing capacity of coal ash to find out its suitability as an embankment material. For this test, unsoaked CBR test was conducted and the CBR mold was filled with 3 layers of ash prepared at OMC based on the Proctor compaction test results. Each layer was compacted with 62 blows and the specimen was placed centrally on the CBR machine. It was then tested under compression with a penetration metal plunger at a penetration rate of $1 \mathrm{~mm} / \mathrm{min}$. Force versus penetration curves were plotted and the CBR values were obtained at specific penetration depths $(2.5 \mathrm{~mm}$ and 5.0 $\mathrm{mm}$ ) while being under compression with the standard forces. The higher of the two measurements was taken as the CBR.

\section{Results and Discussion}

\subsection{Index Properties of the Ash Samples}

Grain size distributions of the FA and BA samples are shown in Figures 1 and 2 respectively. Table 3 shows the variation of the uniformity coefficient $\left(\mathrm{C}_{\mathrm{u}}\right)$ and the coefficient of curvature $\left(C_{c}\right)$ of these coal ash samples. From Figure 1, Figure 2 and Table 3, it can be seen that coal ash has a particle size distribution ranging from the particle size distribution of silt to that of coarse sand. Well graded gravel has a typical $C_{u}$ greater than or equal to 4 and a $C_{c}$ between 1 and 3 . Well graded sand should have a $C_{c}$ in the range 1 to 3 and a $C_{u}$ higher than 6 [9].

$\mathrm{C}_{\mathrm{u}}$ of the all ash samples were greater than 10 and their $C_{c}$ values were within the 1 to 3 range. 
Hence, this ash according to their $C_{u}$ and $C_{c}$ values falls in to the well graded sand category.

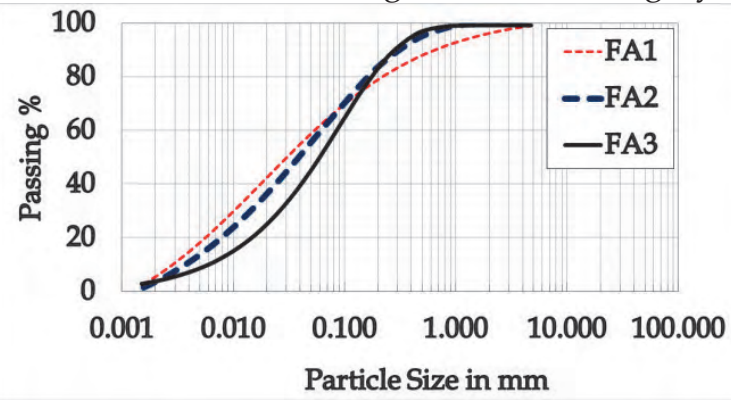

Figure 1 - Gradation curves of FA samples

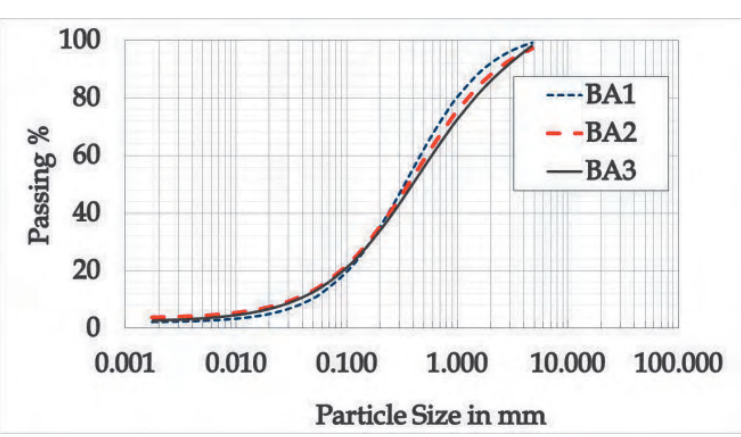

Figure 2 - Gradation curves of BA samples

Table $3-C_{u}$ and $C_{c}$ values of ash samples

\begin{tabular}{|l|c|c|}
\hline Sample & $\mathrm{C}_{\mathbf{u}}$ value & $\mathrm{C}_{\mathbf{c}}$ value \\
\hline FA1 & 18.97 & 1.06 \\
\hline FA2 & 16.22 & 1.15 \\
\hline FA3 & 14.17 & 1.43 \\
\hline BA1 & 10.21 & 1.44 \\
\hline BA2 & 15.59 & 1.60 \\
\hline BA3 & 16.67 & 1.50 \\
\hline
\end{tabular}

In Sri Lanka, the Road Development Authority (RDA) follows ICTAD guidelines in selecting the soil type for road construction. The RDA requirements in respect of soil gradation are given in Table 4. All BA samples were found to satisfy the gradation requirements of RDA, whereas FA samples failed to meet those gradation requirements.

Specific gravities of the tested FA samples FA1, FA2 and FA3, were 2.09, 2.15 and 2.19 respectively while the specific gravities of the BA samples BA1, BA2 and BA3 were 1.89, 1.91 and 1.88 respectively. The average specific gravity of FA and BA were 2.1 and 1.9 respectively, while natural soils have specific gravities between 2.5 and 2.7. Previous studies $[8,9,11]$ also have stated that coal ash has a lower specific gravity than natural soil. The reason for the low specific gravity could either be due to the presence of a large number of hollow spherical particles from which the entrapped air cannot be removed, or the variation in the chemical composition, in particular the iron content, or both [9].

Table 4 - Required grading for sub base specified by RDA

\begin{tabular}{|c|c|}
\hline Sieve size $\mathbf{( m m )}$ & Passing percentage (\%) \\
\hline 50 & 100 \\
\hline 37.5 & $80-100$ \\
\hline 20 & $60-100$ \\
\hline 5 & $30-100$ \\
\hline 1.18 & $17-75$ \\
\hline 0.3 & $9-50$ \\
\hline 0.075 & $5-25$ \\
\hline
\end{tabular}

Indian Road Congress (IRC) has specified the properties of FA that can be used as road embankment material. According to the IRC guideline, FA should possess a specific gravity between 1.90 and 2.55 [5]. The specific gravity of coal ash obtained in this study aligns with the IRC values.

Owing to the non-plastic nature of coal ash, the plastic limit (PL) of the ash could not be calculated. When using Casagrande method to find the liquid limit (LL), it is very difficult to cut a groove in the ash because of its low plasticity and tendency to slip rather than flow. Therefore, LL was calculated using the cone penetration method and the LLs obtained for the FA samples FA1, FA2 and FA3 were $44 \%$, $45 \%$ and $46 \%$, respectively while the corresponding values for the BA samples BA1, BA2 and BA3 were $75 \%, 74 \%$ and $74 \%$ repectively. The average value of LL for FA and BA were $45 \%$ and $74 \%$ respectively.

The LL values of coal ash obtained are not due to their plasticity characteristics but due to their fabric and carbon content [9]. The LL value specified by RDA for Embankment Type I and Type II soils are: (1) LL < 50\% for Embankment Type I soils and (2) LL < 55\% for Embankment Type II soils. Based on RDA guideline on LL, FA can be used as either Embankment Type I or Type II material. All fly ash samples were found suitable for use as Embankment Type I and Type II material as per RDA specifications, whereas none of the BA samples were found suitable for use as embankment material as per the same specifications. 
Figure 3 shows the compaction curves of the FA and BA samples while Figure 4 shows the compaction curves of composite samples (C1, $\mathrm{C} 2$ and $\mathrm{C} 3$ ). The OMC and MDD values of the FA and BA samples are illustrated in Table 5 . FA2 and BA3 by weight were selected for the blended samples as they had the maximum MDD and lowest OMC in their respective categories. MDD and OMC values of the blended samples are also shown in Table 5.

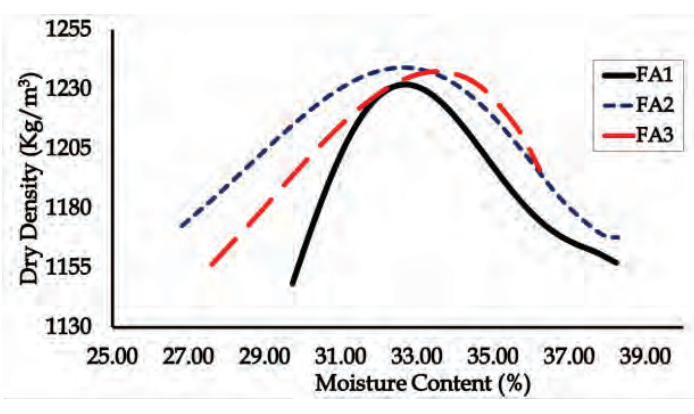

(a) FA samples

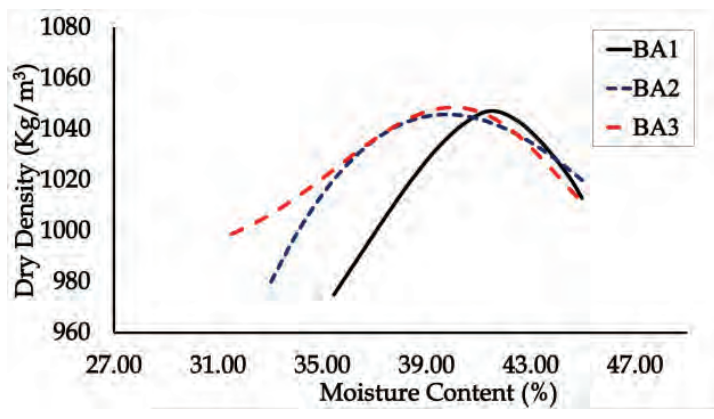

(b)BA samples

Figure 3 - Compaction curves of ash samples (a) FA samples, (b) BA samples

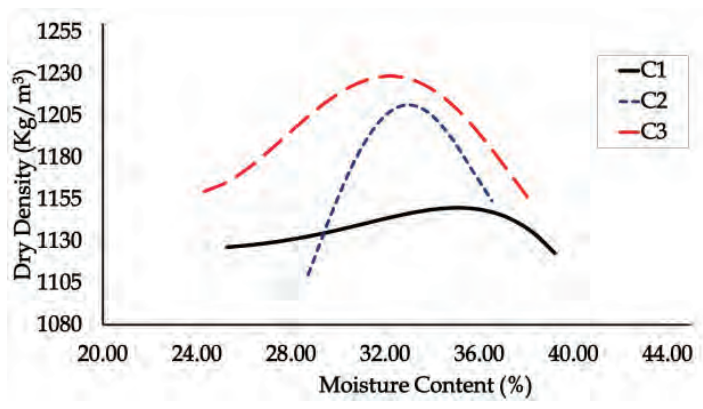

Figure 4 - Compaction curves of composite Samples

Table 5 - MDD and OMC values of the ash samples

\begin{tabular}{|l|c|c|}
\hline Sample & $\begin{array}{c}\text { MDD } \\
\mathbf{( k g / \mathbf { m } ^ { 3 }} \mathbf{~}\end{array}$ & OMC (\%) \\
\hline FA1 & 1231 & 32.70 \\
\hline FA2 & 1239 & 32.80 \\
\hline FA3 & 1238 & 33.60 \\
\hline BA1 & 1047 & 41.60 \\
\hline BA2 & 1046 & 39.90 \\
\hline BA3 & 1049 & 40.00 \\
\hline C1 & 1150 & 35.20 \\
\hline C2 & 1212 & 33.00 \\
\hline C3 & 1229 & 32.20 \\
\hline
\end{tabular}

The average MDD of FA and BA samples were $1236 \mathrm{~kg} / \mathrm{m}^{3}$ and $1047 \mathrm{~kg} / \mathrm{m}^{3}$ respectively, while their average OMC were $33 \%$ and $41 \%$ respectively. Of all the samples tested, FA samples possessed the highest density (Table 5) although the density of each compacted FA sample was still lower than that of conventional earth fill material compacted with the same effort.

This property of coal ash is due to the uniform gradation of its particles but because of carbon it has, it has a lower MDD and a higher OMC [11]. FA was less sensitive to the variation of moisture content than any of the soils which could be due to the higher air void content of FA. Soils normally have an air void content between $1 \%$ and $5 \%$ at MDD whereas FA contains $5 \%$ to $15 \%$ air voids. The higher void content in FA could limit the buildup of pore pressure during compaction, which allows it to be compacted over a larger range of water content [9]. The MDD specified by RDA for embankment material is, (1) MDD> $1600 \mathrm{~kg} / \mathrm{m}^{3}$ for Embankment Type I material and (2) MDD> $1500 \mathrm{~kg} / \mathrm{m}^{3}$ for Embankment Type II material. It should be noted that these limits are based on the modified Proctor compaction test.

In this research, it was the Standard Proctor Compaction Test that was conducted whereas RDA specifications for the MDD are based on the modified Proctor compaction test results. Therefore, a modified Proctor compaction test was conducted for the sample that had the highest MDD according to Standard Proctor Test results (FA2 in Table 5). The MDD obtained using the modified Proctor compaction test on FA2 was $1307 \mathrm{~kg} / \mathrm{m}^{3}$ which does not meet the RDA requirement for road embankment material. However, all the ash samples meet the specifications set by IRC according to the results of the Standard Compaction Test. According to IRC guidelines, 
MDD of FA should be between 900 - 1600 $\mathrm{kg} / \mathrm{m}^{3}$ while its OMC should be in the range $18 \%-38 \%$. Therefore, it can be concluded that this ash can be used as light weight embankment material based on the compaction test results. Previous studies [2,11] also have found coal ash to be suitable for use as light weight embankment material.

\subsection{Direct shear Test Results}

FA2 and BA3 samples were selected from among the raw ash samples for the direct shear test as they had the highest MDD and lowest OMC among the samples of their respective categories. As the composite samples were prepared using a co-mix of FA2 and BA3, these composite samples (C1, C2 and C3) were also used for the direct shear test. The normal stresses used to determine the maximum shear stress were 50, 100 and $150 \mathrm{kPa}$ respectively for each sample. The variation of shear stress with horizontal shear displacement $(\mathrm{mm})$ for FA2 and BA3 are shown in Figure 5.

Maximum shear stress is taken as the peak shear stress on the shear stress $(\mathrm{kPa})$ versus horizontal shear displacement $(\mathrm{mm})$ curve. In order to establish shear strength parameters (cohesion and angle of internal friction) of the compacted ash samples, a plot of maximum shear stress (ordinate) versus normal stress was made (Figure 6). A straight line (best fit) was drawn through the plotted points and extended to intersect the ordinate. The shear stress intercept gives the cohesion (c) while the slope of the line gives the angle of internal friction $(\phi)$ of the sample. Table 6 shows the shear strength parameters and MDD of FA, BA and blended samples. The MDD of the tested samples given in Table 6 are very close to the MDD obtained for the respective samples from the standard compaction test (Table 5). From Table 6, it can be noticed that $c$ and $\phi$ of BA are higher compared to those of FA. Under dry conditions, the mechanical properties of the incinerator $\mathrm{BA}$ are mainly influenced by the $\mathrm{Al}_{2} \mathrm{O}_{3}$ and $\mathrm{Fe}_{2} \mathrm{O}_{3}$ content, because the shear strength parameters of BA are similar to those of sand and gravel.

Each of the mixes has a higher shear strength and a lower density, and therefore they will develop lower normal stresses on foundation soils, thereby reducing the settlement [9]. Shear strength parameters ( $c$ and $\phi$ ) of the blended samples fall in between those of FA and BA. The friction angle of each sample was between $30^{\circ}$ and $40^{\circ}$, and thus according to IRC guidelines they can be used as light weight embankment material.

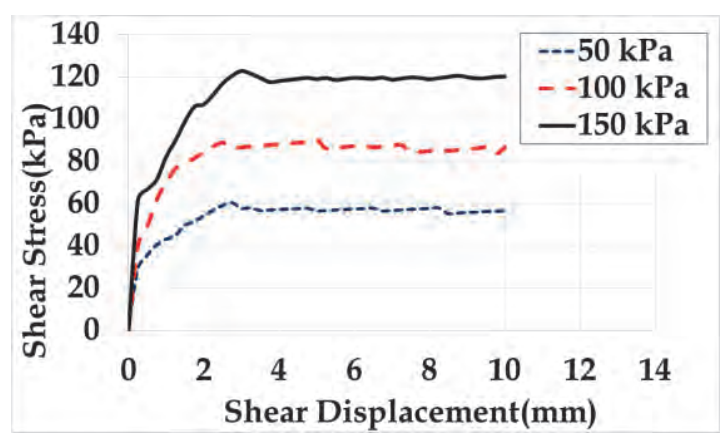

(a) FA2

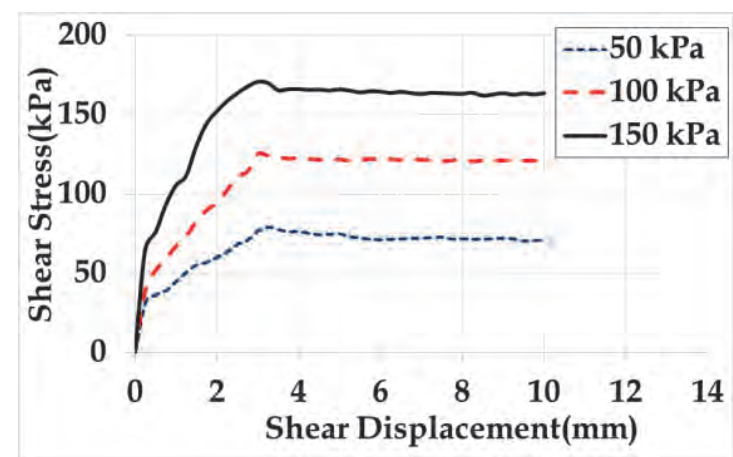

(b) BA3

Figure 5 - Shear stress vs. shear displacement (a) FA2, (b) BA3

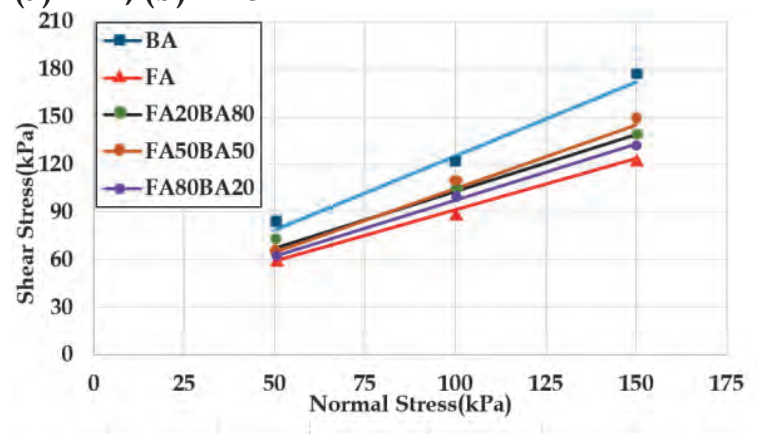

Figure 6 - Shear stress and shear displacement of ashsample

Table 6 -Shear strength parameters (c and $\phi$ ) and the density of ash samples

\begin{tabular}{|l|c|c|c|}
\hline Sample & $\boldsymbol{\phi ( \mathbf { 0 } )}$ & $\mathbf{c}(\mathbf{k P a})$ & $\boldsymbol{M D D} \mathbf{( k g / \mathbf { m } ^ { 3 } )}$ \\
\hline FA2 & 32.7 & 26.4 & 1232 \\
\hline BA3 & 42.9 & 32.4 & 1042 \\
\hline C1 & 35.5 & 31.3 & 1138 \\
\hline C2 & 38.6 & 24.8 & 1209 \\
\hline C3 & 35.1 & 27.0 & 1220 \\
\hline
\end{tabular}

\subsection{CBR Test Results}

CBR test was also conducted on FA2, BA3 samples and their blended samples (C1, C2 and C3) as FA2 and BA3 yielded had maximum MDD and lowest OMC respectively among the fly ash and bottom ash samples. CBR curves of FA2, BA3 and blended samples (C1, C2 and C3) are shown in Figure 7. CBR calculated for each 
sample using information presented in Figure 7 are given in Table 7. CBR of the ash is in the range expected for silts and very fine sands [9].

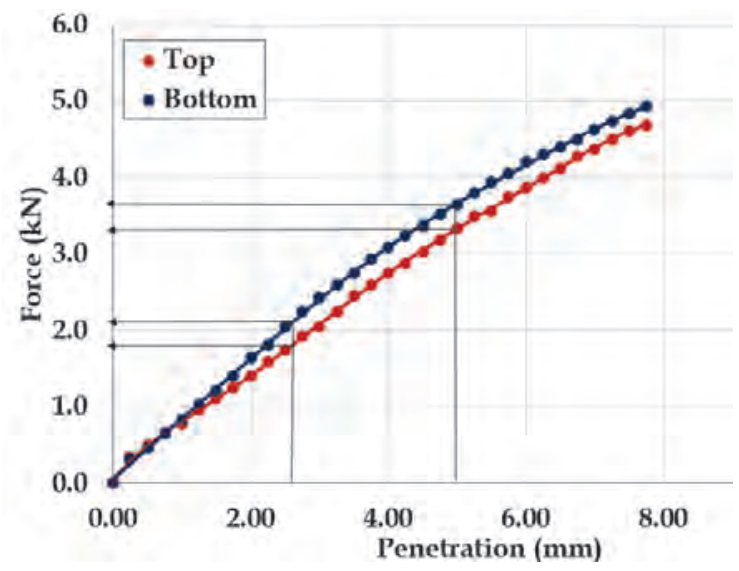

(a) FA2

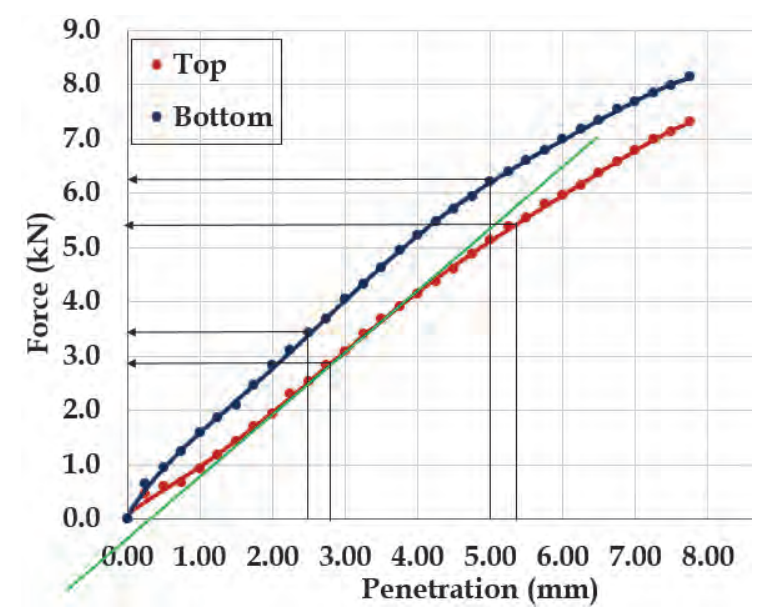

(b) BA3

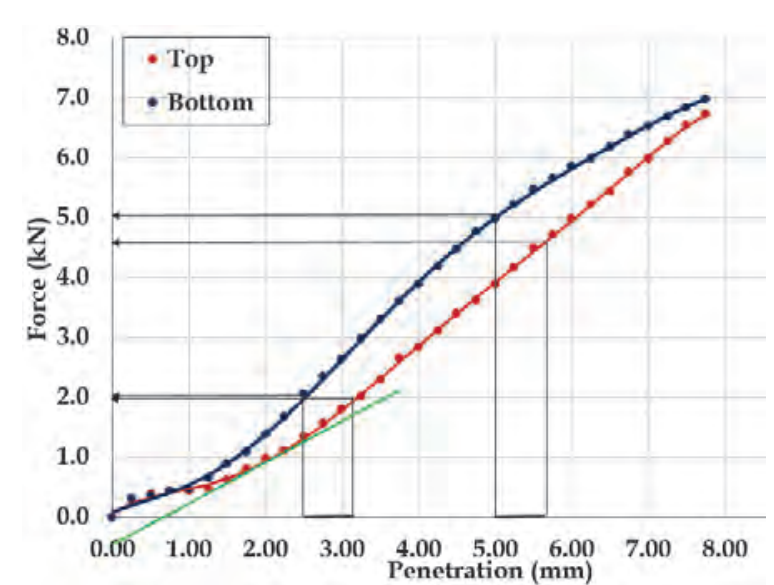

(c) $\mathrm{C} 1$

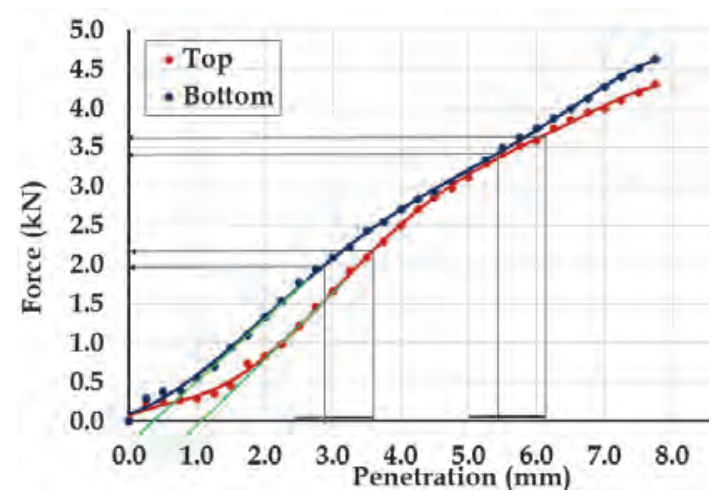

(d) $\mathrm{C2}$

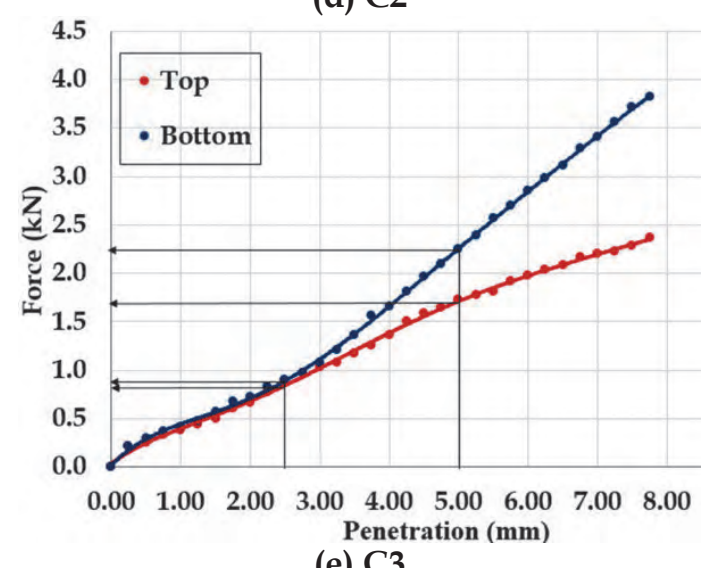

(e) $\mathrm{C} 3$

Figure 7 - CBR curves for tested samples (a) FA2, (b) BA3, (c) C1, (d) C2,(e) C3

Table 7 - CBR of ash samples

\begin{tabular}{|l|c|c|c|}
\hline Sample & $\begin{array}{c}\text { CBR value } \\
\mathbf{( \% )}\end{array}$ & $\begin{array}{c}\text { OMC } \\
\mathbf{( \% )}\end{array}$ & $\begin{array}{c}\text { MDD } \\
\mathbf{( k g / \mathbf { m } ^ { 3 } \mathbf { ~ }}\end{array}$ \\
\hline FA2 & 17.4 & 32.7 & 1232 \\
\hline BA3 & 28.8 & 41.9 & 1042 \\
\hline C1 & 22.8 & 34.9 & 1138 \\
\hline C2 & 17.0 & 33.2 & 1209 \\
\hline C3 & 9.9 & 33.0 & 1220 \\
\hline
\end{tabular}

In this research, it is the unsoaked CBR test that was conducted, whereas RDA specification for $\mathrm{CBR}$ is for the four day soaked CBR at $98 \%$ MDD. Therefore, a four day soaked CBR test was conducted for the FA2 sample (as this yielded the highest MDD and the lowest OMC) at $98 \%$ MDD under modified Proctor compaction conditions and the CBR obtained was $9.0 \%$. RDA specification of 4 day soaked CBR at $98 \%$ MDD for Embankment material include, (1) CBR> 7\% for Embankment Type I material and (2) CBR> 5\% for Embankment Type II material. FA2 satisfies the RDA specified CBR for embankment material. Previous studies have also found that unsoaked CBR values of FA vary between $8.4-20.6 \%$ [9], 
and that as such FA and BA can be used as light weight embankment material. Since the CBR of all the tested ash exceed $9 \%$, it can be concluded that they can be used as light weight embankment material.

\subsection{Suitability of Coal Ashes as Embankment Material Considering the Overall Outcome}

In the previous sections, the suitability of each ash type as an embankment material was discussed based on the individual test results (index properties, Proctor compaction test, direct shear test and CBR test). The summary of the conclusions made on the suitability of FA as an embankment material based on the results of the different tests carried out on the FA sample are shown in Table 8.

It can be noted from Table 8 that several test results meet the requirements stated in the RDA and IRC guidelines while some test results do not meet the requirements of either of these guidelines. However, previous studies $[1-4,9,11]$ have concluded that this ash (FA, BA and their blended mix) can be used as a light weight embankment material.
The geotechnical engineering parameters of FA, BA and blended samples obtained during the current study are in good agreement with their values obtained in the previous studies $[3,5,8$, 9]. However, as this ash does not meet RDA specifications, it is not possible to use it as an embankment material for heavily loaded embankments. However, it should be possible to use this ash as a light weight embankment material for construction purposes.

\section{Conclusions}

An experimental program was conducted to study the suitability of coal ash produced by the Lakvijaya power plant for use as in embankments. Altogether nine samples were tested including three fly ash samples (FA1, FA2 and FA3), three bottom ash samples (BA1, BA2 and BA3) and three FA-BA co-mixed samples (C1, C2 and C3). Conclusions made based on the findings are detailed below.

Table 8 - Summary of conclusions made from different tests

\begin{tabular}{|c|c|c|c|c|c|c|}
\hline Sample & $\begin{array}{l}\text { Grain Size } \\
\text { Analysis } \\
\text { test }\end{array}$ & $\begin{array}{l}\text { Specific } \\
\text { Gravity test }\end{array}$ & $\begin{array}{l}\text { LL } \quad \text { (based } \\
\text { on Cone } \\
\text { Penetration } \\
\text { Test) }\end{array}$ & $\begin{array}{l}\text { Standard } \\
\text { Proctor test }\end{array}$ & $\begin{array}{l}\text { Direct } \\
\text { Shear test }\end{array}$ & CBR test \\
\hline $\begin{array}{l}\text { FA } \\
\text { (FA1- } \\
\text { FA3) }\end{array}$ & $\begin{array}{l}\text { Does not } \\
\text { satisfy } \\
\text { requirement }\end{array}$ & $\begin{array}{l}\text { Satisfies IRC } \\
\text { requirement }\end{array}$ & $\begin{array}{l}\text { Satisfies } \\
\text { RDA } \\
\text { requirement }\end{array}$ & $\begin{array}{l}\text { Does not } \\
\text { satisfy RDA } \\
\text { requirement; } \\
\text { satisfies IRC } \\
\text { requirement }\end{array}$ & $\begin{array}{l}\text { Satisfies IRC } \\
\text { requirement }\end{array}$ & $\begin{array}{l}\text { Tested } \\
\text { sample (FA2) } \\
\text { satisfies RDA } \\
\text { requirement }\end{array}$ \\
\hline $\begin{array}{l}\text { BA } \\
\text { (BA1- } \\
\text { BA3) }\end{array}$ & $\begin{array}{l}\text { Satisfies } \\
\text { RDA } \\
\text { requirement }\end{array}$ & - & $\begin{array}{l}\text { Does not } \\
\text { satisfy } \\
\text { requirement }\end{array}$ & $\begin{array}{lr}\text { Does } & \text { not } \\
\text { satisfy } & \text { RDA } \\
\text { requirement }\end{array}$ & - & \multirow{4}{*}{$\begin{array}{l}\text { Unsoaked } \\
\text { CBR values } \\
\text { obtained do } \\
\text { not tally } \\
\text { with those } \\
\text { reported in } \\
\text { the literature } \\
\text { [9] }\end{array}$} \\
\hline $\mathrm{C} 1$ & - & $\begin{array}{l}\text { Satisfies IRC } \\
\text { requirement }\end{array}$ & - & $\begin{array}{l}\text { Does not } \\
\text { satisfy RDA } \\
\text { requirement; } \\
\text { satisfies IRC } \\
\text { requirement }\end{array}$ & $\begin{array}{l}\text { Satisfies IRC } \\
\text { requirement }\end{array}$ & \\
\hline C2 & - & $\begin{array}{l}\text { Satisfies IRC } \\
\text { requirement }\end{array}$ & - & $\begin{array}{l}\text { Does not } \\
\text { satisfy RDA } \\
\text { requirement; } \\
\text { satisfies IRC } \\
\text { requirement }\end{array}$ & $\begin{array}{l}\text { Satisfies IRC } \\
\text { requirement }\end{array}$ & \\
\hline C3 & - & $\begin{array}{l}\text { Satisfies IRC } \\
\text { requirement }\end{array}$ & - & $\begin{array}{l}\text { Does not } \\
\text { satisfy RDA } \\
\text { requirement; } \\
\text { satisfies IRC } \\
\text { requirement }\end{array}$ & $\begin{array}{l}\text { Satisfies IRC } \\
\text { requirement }\end{array}$ & \\
\hline
\end{tabular}


Grain size distribution results reveal that the this ash (FA and BA) is similar to well graded sand range as far as grain size distribution is concerned, and that the gradation of BA meets the RDA requirement for embankment material, whereas the gradation of FA does not meet the RDA requirement. Specific gravity of FA and BA are lower than that of typical backfill material, and these lower specific gravities will be advantageous to reduce the settlement due to the weight of the embankment.

Liquid Limit (LL) value of FA falls within the range specified by RDA for Embankment Type I and Type II material, whereas none of the BA samples are suitable to be used as embankment material according to Atterberg limits specified in the RDA guideline. Maximum dry density (MDD) and optimum moisture content (OMC) obtained for FA and BA samples by carrying out the Standard Proctor Test on them meet the IRC requirements for Embankment material, whereas none of the FA, BA and blended samples are within the limits specified by RDA based on modified Proctor test results. Shear strength parameters $(c$ and $\phi$ ) obtained for FA and BA are in agreement with the previous findings and the friction angle values $(\phi)$ satisfy the requirement set out in the IRC guideline. CBR obtained for coal ash is in agreement with the previous findings, and the 4 day soaked CBR obtained for fly ash satisfies the specification given in the RDA requirement for embankment material.

None of the tested ash mixes (FA1-FA3, BA1BA3 and C1-C3) satisfies all the requirements set out in RDA and IRC guidelines for a typical embankment material. However, some test results satisfy the requirements set out in those guidelines. Previous findings on coal ash (FA, BA and their blended mix) also suggest that this ash can be used as a light weight embankment material. It can thus be concluded that coal ash produced by the Lakvijaya coal power plant can be used as light weight embankment material in construction work.

\section{References}

1. Havanagi, V. G., Sinha, A. K., Mathur, S., 2011. Design and Stability Analysis of Pond Ash Railway Embankment. In: Indian Geotechnical Society. Indian Geotechnical Conference. kochchi, India, 15-17 December 2011. India.

2. Kaniraj, S. R., Gayathri, V., 2004. Permeability and Consolidation Characteristics of Compacted
Fly Ash. The Journal of Energy Engineering. 130(1), pp.18-43.

3. Kim, B., Prezzi, M., Salgado, R., 2005. Geotechnical Properties of Fly and Bottom Ash Mixtures for Use in Highway Embankments. Journal of Geotechnical and Geoenvironmental Engineering, 131(7), pp.914-924.

4. Kumar, S., Stewart, J., 2003. Evaluation of Illinois Pulverized Coal Combustion Dry Bottom Ash for Use in Geotechnical Engineering Applications. The Journal of Energy Engineering, 129(2), pp.56-45.

5. Malik, F. A., Borole, R. U., Kulkarni, S. S., Bhusawal, T., 2010. Management of Fly Ash in Construction of National Highway Projects. International Journal of Scientific Research and Management Studies (IJSRMS), 2(3), pp.150-156.

6. Martin, J. P., Collins, R. A., Browning, J. S., Biehl, F. J., 1990. Properties and Use of Fly Ashes for Embankments. Journal of Energy Engineering, 116(2), pp.71-86.

7. Muhunthan, B., Taha, R., Said, J., 2004. Geotechnical Engineering Properties of Incinerator Ash Mixes. Journal of the Air E Waste Management Association, 54(8), pp.985-991.

8. Pandey, V. C., Singh, N., 2010. Impact of Fly Ash Incorporation in Soil Systems. Agriculture, Ecosystems and Environment, 136, pp.16-27.

9. Pandian, N. S., 2004. Fly Ash Characterization with Reference to Geotechnical Applications. Journal of Indian Institute of Science, 84(6), pp.189216.

10. Priyadarshana, T., 2016. High Performance Concrete Comprising nano and Micro Silica with Fly Ash. PhD thesis. University of Peradeniya.

11. Singh, R. R., Goyal, N., Kaur, N., 2015. Fly Ash as an Embankment Material. SSRG International Journal of Civil Engineering (SSRG-IJCE), 3(3), pp.14-16. 